\title{
Role of Integrins in Modulating Smooth Muscle Cell Plasticity and Vascular Remodeling: From Expression to Therapeutic Implications
}

\author{
Manish Jain ${ }^{1, *(\mathbb{D})}$ and Anil K. Chauhan ${ }^{2, *(D)}$ \\ 1 Pharmacology Division, University Institute of Pharmaceutical Sciences (UIPS), Panjab University, \\ Chandigarh 160014, India \\ 2 Department of Internal Medicine, Division of Hematology/Oncology, University of Iowa, \\ Iowa City, IA 52242, USA \\ * Correspondence: manishjain.cdri@gmail.com (M.J.); anil-chauhan@uiowa.edu (A.K.C.); \\ Tel.: +91-9041544727 (M.J.); +1-319-335-6525 (A.K.C.); Fax: +91-1722541142 (M.J.); +1-319-353-8383 (A.K.C.)
}

Citation: Jain, M.; Chauhan, A.K. Role of Integrins in Modulating Smooth Muscle Cell Plasticity and Vascular Remodeling: From Expression to Therapeutic Implications. Cells 2022, 11, 646. https://doi.org/10.3390/ cells11040646

Academic Editor: András Balla

Received: 18 January 2022

Accepted: 11 February 2022

Published: 13 February 2022

Publisher's Note: MDPI stays neutral with regard to jurisdictional claims in published maps and institutional affiliations.

Copyright: (c) 2022 by the authors. Licensee MDPI, Basel, Switzerland. This article is an open access article distributed under the terms and conditions of the Creative Commons Attribution (CC BY) license (https:/ / creativecommons.org/licenses/by/ $4.0 /)$.

\begin{abstract}
Smooth muscle cells (SMCs), present in the media layer of blood vessels, are crucial in maintaining vascular homeostasis. Upon vascular injury, SMCs show a high degree of plasticity, undergo a change from a "contractile" to a "synthetic" phenotype, and play an essential role in the pathophysiology of diseases including atherosclerosis and restenosis. Integrins are cell surface receptors, which are involved in cell-to-cell binding and cell-to-extracellular-matrix interactions. By binding to extracellular matrix components, integrins trigger intracellular signaling and regulate several of the SMC function, including proliferation, migration, and phenotypic switching. Although pharmacological approaches, including antibodies and synthetic peptides, have been effectively utilized to target integrins to limit atherosclerosis and restenosis, none has been commercialized yet. A clear understanding of how integrins modulate SMC biology is essential to facilitate the development of integrin-based interventions to combat atherosclerosis and restenosis. Herein, we highlight the importance of integrins in modulating functional properties of SMCs and their implications for vascular pathology.
\end{abstract}

Keywords: integrins; smooth muscle cell; phenotype switching; neointimal hyperplasia; restenosis; extracellular matrix; fibronectin

\section{Introduction}

Vascular smooth muscle cells (SMCs), present in the media layer of arteries, are critical to maintain the vascular tone of resistance arteries through synergic action between vasodilators/vasoconstrictors and vascular SMC contractility. SMCs exist in a differentiated, contractile, non-proliferative state in healthy arteries and exhibit an elongated myocyte morphology. Differentiated SMCs are characterized by the expression of a repertoire of smooth muscle-specific contractile and cytoskeletal proteins (e.g., SM-myosin heavy chain (MYH11), smooth muscle alpha-actin (ACTA2), SM22 $\alpha$ (TAGLN), calponin (CNN1), hcaldesmon (CALD1), and smoothelin $(S M T N)$ ), all of them required to maintain the integrity of the arterial wall [1]. Unlike other differentiated cells, SMCs are not terminally differentiated and have the flexibility to shift from a contractile to a proliferative, pro-migratory, synthetic phenotype, exhibiting a rhomboid morphology. These de-differentiated SMCs are characterized by reduced expression of contractile proteins [2]. The transition of SMCs from a "contractile" to a "synthetic" phenotype is known as SMC phenotypic modulation or switching, which contributes to SMC proliferation, and migration, and thereby plays a vital role in the progression of atherosclerosis, in-stent restenosis, and other cardiovascular hyperplastic disorders. Additionally, platelet-derived growth factor (PDGF), transforming growth factor-beta (TGF- $\beta$ ), cytokines, integrins, angiotensin II, nitric oxide, reactive oxygen species, and the components of the extracellular matrix (ECM) are known to modulate 
SMC phenotype [3-6]. These dedifferentiated SMCs re-enter the cell cycle and secrete ECM components, including fibronectin, which contributes to vascular remodeling. In fact, lineage-tracing experiments suggest that phenotypically modulated SMCs within lesions can comprise about $\sim 30 \%$ of the total cell count [7]. In healthy arteries, SMCs are surrounded by ECM components including laminin, collagen type IV, and heparan sulfate proteoglycan. Following injury, SMC activation is associated with marked changes in ECM composition, such as the disappearance of laminin and other basement membrane structures, and the appearance of abundant deposits of fibronectin and vitronectin around proliferative cells in the media and intima [8,9], suggesting a functional role of ECM in SMC activation. Integrins are the primary ECM receptors that regulate cell-cell and cell-ECM interactions. Furthermore, the adhesion, proliferation, and migration of SMCs are regulated by the interaction of integrins with ECM components [10].

\section{Integrins: A Brief Overview}

Integrins are transmembrane heterodimeric receptors that bind to cytoskeletal proteins of SMCs, including talin, vinculin, $\alpha$-actinin, and filamin, and play a key role in SMC biology and in the development, maintenance, and remodeling of the vasculature [11-13]. The integrin family includes 18 alpha $(\alpha)$ and 8 beta $(\beta)$ subunits that form 24 distinct $\alpha \beta$ heterodimers. Each integrin heterodimer consists of a large extracellular domain region, two single-pass transmembrane helices (one in each subunit), and short cytoplasmic tails $[14,15]$. Integrins are known to adopt three central conformational states: inactive (low affinity, predominant state), active (high affinity, intermediate state), and ligand occupied (active state). Integrins can transmit signals from inside the cell to outside (inside-out signaling) and from outside to inside the cell (outside-in signaling). The process involves intracellular binding of ligands to the cytoplasmic domain, which causes a major change in the extracellular domain of the integrin receptor, leading to a high affinity for extracellular ligands [16,17]. Integrin outside-in signaling regulates cell growth, cell survival, and SMCECM interaction $[2,16]$. The activation of cell surface receptors, including growth factor receptors and cytokine receptors, also results in some conformational change in integrin receptors that, in turn, modulates its ligand-binding characteristics.

Depending on their ligand recognition pattern, integrins are classified as lamininbinding integrins ( $\alpha 3 \beta 1, \alpha 6 \beta 1, \alpha 7 \beta 1$, and $\alpha 6 \beta 4)$, collagen-binding integrins $(\alpha 1 \beta 1, \alpha 2 \beta 1$, $\alpha 10 \beta 1$, and $\alpha 11 \beta 1$ ), leukocyte-binding integrins, and Arg-Gly-Asp (RGD) binding integrins [14]. Laminin-binding integrins mediate the adhesion of cells to basement membranes; collagen-binding integrins mediate the adhesion of cells to collagen and chondroadherin; leucocyte-binding integrins bind intercellular adhesion molecule (ICAM) and plasma proteins. In contrast, RGD-binding integrins recognize three amino acid motifs, the 'arginineglycine-aspartic acid' sequence commonly found in several ECM components, including vitronectin, fibronectin, fibrinogen, and von Willebrand factor [14]. Among the 24 human integrin subtypes known to date, eight integrin dimers recognize the tripeptide RGD motif within ECM proteins, namely: $\alpha \mathrm{v} \beta 1, \alpha \mathrm{v} \beta 3, \alpha \mathrm{v} \beta 5, \alpha \mathrm{v} \beta 6, \alpha \mathrm{v} \beta 8, \alpha 5 \beta 1, \alpha 8 \beta 1$, and $\alpha \operatorname{IIb} \beta 3$.

\section{Role of Integrins in SMC Biology}

Integrin signaling plays an essential role in SMC biology by regulating adhesion, migration, proliferation, contraction, and differentiation [10,16,18-21]. Several proteins such as integrin-associated protein, integrin-linked kinase, focal adhesion kinase (FAK), tetraspanin CD9, and urokinase-type plasminogen activator receptor modulate integrinmediated cell motility and adhesion in SMCs [10,22-25]. Integrin signaling in SMC also involves growth factor receptors that crosstalk between signaling pathways $[17,26]$. Several studies suggest that synergism may occur between integrin and downstream signaling molecules $[17,27]$. For example, integrin-mediated adhesion to ECM can enhance growth factor signaling on its receptor. In some cases, interactions with ECM may aid in the effective presentation of the growth factors to their receptors [28]. Additionally, integrin activation includes receptor tyrosine phosphorylation [29]. For instance, integrin-ligand adhesion 
triggers FAK auto-phosphorylation at tyrosine (Tyr) 397, which prompts FAK association with steroid receptor coactivator (Src). Src then phosphorylates other tyrosine residues that contribute to the full activation of FAK [25]. The activated FAK/Src complex facilitates various key signaling cascades, including the activation of serine-threonine protein kinase $(\mathrm{AKT})$, extracellular signal-regulated kinase (ERK), and p38 mitogen-activated protein kinase (MAPK) pathway [30,31], all of which are known to regulate SMC proliferation and migration. A schematic summary of the proposed mechanism is shown (Figure 1).

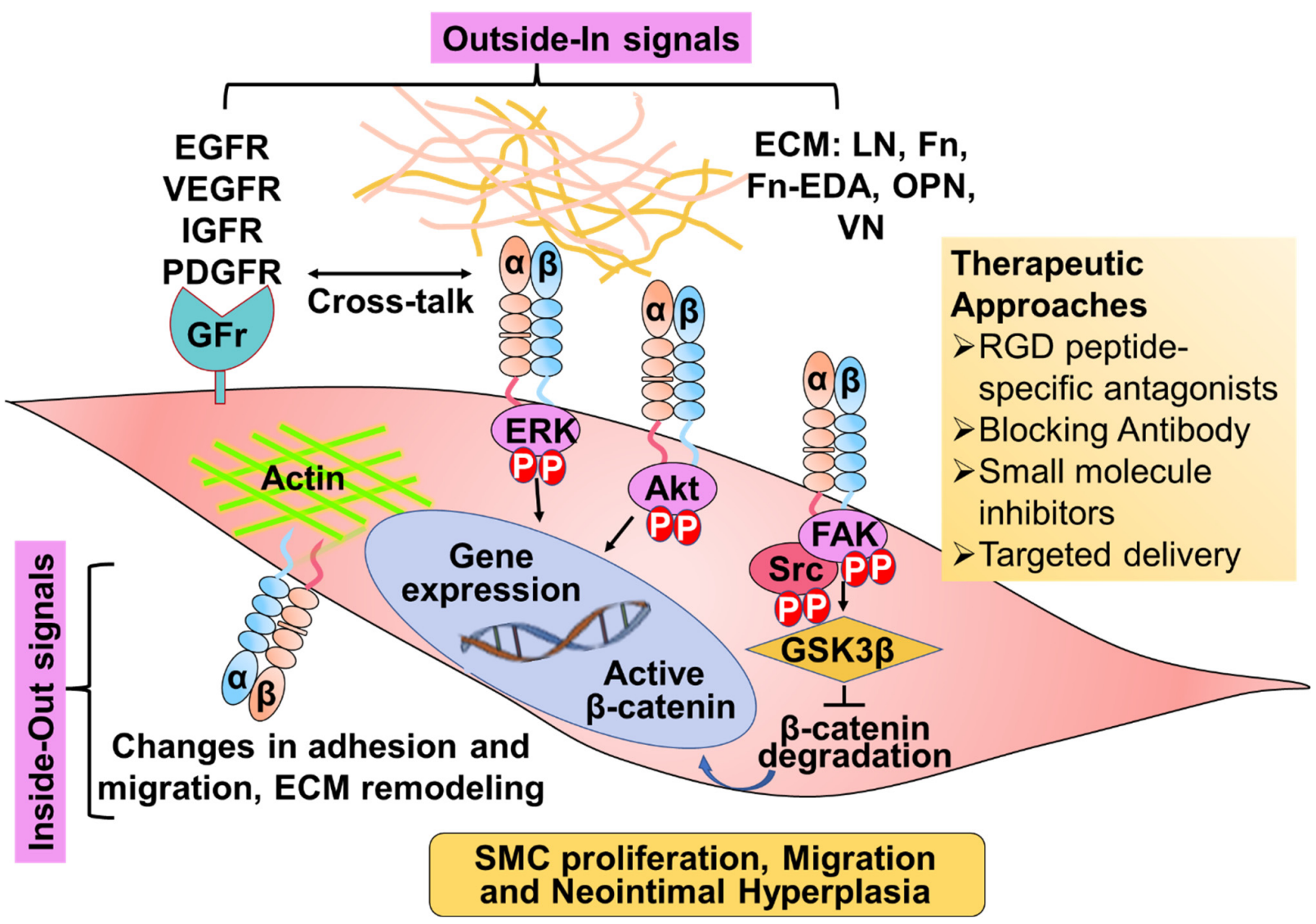

Figure 1. Schematic showing the signal transduction pathways regulated by integrins in smooth muscle cells (SMC). Depending on the type of integrin and its expression on SMCs, they can trigger signals promoting synthetic or paradoxically a contractile SMC phenotype. Many of the reported SMCspecific integrins promote synthetic SMC phenotype. For example, integrin binding to extracellular matrix (ECM) or activation of growth factor receptors (GFr) facilitates downstream signaling events via FAK-Src, Akt, or ERK pathway, resulting in SMC proliferation and migration and neointimal migration hyperplasia. Abbreviations: ERK: extracellular signal-regulated kinase; ECM: extracellular matrix; EDA: extra domain A; FAK: focal adhesion kinase, Fn: Fibronectin; IGFR: insulin-like growth factor receptor; LN: Laminin; OPN: Osteopontin; PDGFR: platelet-derived growth factor receptor; VEGFR: vascular endothelial growth factor receptor; VN: Vitronectin.

Integrin-ligand interactions play a crucial role in remodeling of the injured vessel wall during wound healing, arterial stent injury, and in maintaining typical vascular structure [32]. Several integrins contribute to SMC activation. The major $\alpha$-integrin subunits present in SMC are $\alpha 1, \alpha 3, \alpha 5, \alpha 8$, and $\alpha 9[10,33]$, whereas $\beta$ subunits are $\beta 1, \beta 3$, and $\beta 5$. The expression of integrins is dynamic and varies dramatically in SMC with different phenotypes [21,33]. Few integrins are upregulated in activated SMC, while expression levels are very low or undetectable in differentiated quiescent SMCs [21]. For example, integrin $\alpha 1 \beta 1$ is a collagen-binding integrin that is highly expressed in resting SMCs, and its expression is significantly downregulated in culture conditions [34]. Similarly, integrin $\alpha 8 \beta 1$ is overex- 
pressed in SMCs that display a contractile phenotype, and its expression is downregulated after vascular injury [35]. Studies have demonstrated that the downregulation of integrin $\alpha 8 \beta 1$ causes actin filaments (a hallmark feature of contractile SMC phenotype) to dissociate and subsequently disintegrate, favoring a synthetic SMC phenotype [12]. Other integrins, including $\alpha 2 \beta 1, \alpha 5 \beta 1, \alpha 5 \beta 3$, and $\alpha 4 \beta 1$, are often expressed on the surface of SMCs in a low-affinity ligand-binding conformation [18,19,36-39]. The $\alpha 5 \beta 1$, which is a receptor for fibronectin, is poorly expressed in quiescent vessels in vivo. Following injury, fibronectin and integrin $\alpha 5 \beta 1$ expression is upregulated [18]. Another integrin subunit $\beta 3$ is also known to be upregulated in response to stimuli, such as mechanical injury and neointimal hyperplasia, whereas blocking $\beta 3$ attenuates SMC migration [40]. Several other integrins, including $\alpha 2 \beta 1, \alpha 5 \beta 1, \alpha 5 \beta 3$, and $\alpha 4 \beta 1$, are known to contribute to SMC migration and synthetic phenotype [38,41], whereas $\alpha 1 \beta 1$ [42] and $\alpha 7 \beta 1$ [20] were shown to mediate the phenotypic switch of SMCs.

\section{Role of Integrins in Neointimal Hyperplasia}

Neointimal hyperplasia refers to post-intervention, pathological vascular remodeling due to the proliferation and migration of SMCs into the intimal layer, resulting in vascular wall thickening. During neointimal recruitment, SMCs are exposed to various ECM proteins, and integrin-ECM signaling has been shown to drive smooth muscle fibroproliferative remodeling. Several integrins are also known to promote neointimal hyperplasia, and evidence suggests that blocking integrins such as $\alpha \operatorname{IIb} \beta 3$ [43] and $\alpha 4 \beta 1[44,45]$ prevents neointimal hyperplasia. Besides these, the current literature strongly supports a role of signaling through $\alpha \mathrm{v} \beta 3$ in SMCs during neointimal hyperplasia [32]. In humans, $\alpha v \beta 3$ is present in normal arteries and at the sites of SMC accumulation in atherosclerotic plaques. Several studies have shown that targeting $\alpha v \beta 3$ integrin limits neointimal hyperplasia in small animal models of restenosis, including rat, rabbit, hamster, and guinea pig carotid angioplasty models [32,40,46,47]. In addition, an antibody to $\beta 3$ integrin was demonstrated to prevent the development of intimal hyperplasia in wild-type diabetic mice [48]. Although $\beta_{3}$-integrin blockade effectively reduces neointimal hyperplasia in animal models, the genetic ablation of $\beta 3$ was found not to be effective for preventing intimal hyperplasia in animal models [49]. Therefore, it was speculated that the genetic loss of $\beta 3$ might result in compensatory increases in the number and affinity of other adhesion receptors. In contrast, such compensation probably cannot occur with acute inhibition of $\alpha v \beta 3$. In addition, the absence of $\beta 3$ may affect signaling mediated by other integrins by decreased binding of intracellular proteins involved in signaling that ordinarily bind to the cytoplasmic domain of the missing integrin. Besides its detrimental role, some integrins are also known to prevent neointimal hyperplasia, such as $\alpha 8 \beta 1$ [50] and $\alpha 7 \beta 1$ [51]. The expression of different integrins on SMC, their ECM ligand, and their possible role in SMC function and neointimal hyperplasia are summarized in Table 1.

Table 1. Table representing the expression of different integrin subunits, their implication in smooth muscle cell (SMC) function and disease conditions such as atherosclerosis and neointimal hyperplasia, and integrin-directed drugs used in clinics. Collagen, Col; Laminin, LN; Fibronectin, Fn; Vascular cell adhesion molecule, VCAM; Osteopontin, OPN; Tenascin, TN; Vitronectin, VN; Fibrinogen, Fib; EDA, extra domain A.

\begin{tabular}{ccccccc}
\hline Integrin & ECM & SMC Expression & SMC Function & $\begin{array}{c}\text { Implication in } \\
\text { Atherosclero- } \\
\text { sis/Restenosis }\end{array}$ & $\begin{array}{c}\text { Integrin-Targeting } \\
\text { Agents in Clinics }\end{array}$ \\
\hline$\alpha 1 \beta 1$ & Col 1-IV, LN & $\begin{array}{c}\text { High expression in } \\
\text { resting SMCs. } \\
\text { Downregulated in } \\
\text { culture conditions and } \\
\text { during neointimal } \\
\text { hyperplasia }\end{array}$ & $\begin{array}{c}\text { Promotes SMC } \\
\text { adhesion and } \\
\text { contractile } \\
\text { phenotype }\end{array}$ & $\begin{array}{c}\alpha 1 \beta 1 \text { deletion } \\
\text { induces a stable } \\
\text { plaque phenotype }\end{array}$ & SAN-300 & {$[10,34,42,52-55]$} \\
\hline
\end{tabular}


Table 1. Cont.

\begin{tabular}{|c|c|c|c|c|c|c|}
\hline Integrin & ECM & SMC Expression & SMC Function & $\begin{array}{l}\text { Implication in } \\
\text { Atherosclero- } \\
\text { sis/Restenosis }\end{array}$ & $\begin{array}{l}\text { Integrin-Targeting } \\
\text { Agents in Clinics }\end{array}$ & Reference \\
\hline$\alpha 2 \beta 1$ & $\begin{array}{l}\text { Col } 1 \text { and IV, } \\
\text { LN }\end{array}$ & $\begin{array}{l}\text { Undetectable levels in } \\
\text { normal human SMCs, } \\
\text { and high expression in } \\
\text { cultured SMCs }\end{array}$ & $\begin{array}{l}\text { promote } \\
\text { chemotaxis of } \\
\text { arterial SMCs }\end{array}$ & $\begin{array}{c}\alpha_{2} \beta_{1} \text { deletion had } \\
\text { no effect on } \\
\text { atherosclerosis }\end{array}$ & Vatelizu-mab & {$[16,39,42,52,56]$} \\
\hline$\alpha 3 \beta 1$ & $\begin{array}{c}\text { Col 1, Fn, and } \\
\text { LN }\end{array}$ & $\begin{array}{c}\text { Detectable levels in } \\
\text { normal human SMCs, } \\
\text { and high expression in } \\
\text { cultured SMCs }\end{array}$ & \multicolumn{3}{|c|}{ No conclusive reports } & {$[10,33]$} \\
\hline$\alpha 4 \beta 1$ & $\begin{array}{l}\text { Cellular-Fn, } \\
\text { VCAM, OPN }\end{array}$ & $\begin{array}{l}\text { Undetectable levels in } \\
\text { normal human SMCs, } \\
\text { expressed in SMCs in } \\
\text { culture and in intimal } \\
\text { atherosclerotic } \\
\text { thickening }\end{array}$ & $\begin{array}{c}\text { Induction of SMC } \\
\text { differentiation }\end{array}$ & $\begin{array}{l}\text { blocking } \alpha_{4} \beta_{1} \\
\text { prevents } \\
\text { neointimal } \\
\text { hyperplasia }\end{array}$ & $\begin{array}{c}\text { Natalizu-mab } \\
\text { AJM300 }\end{array}$ & {$[38,44,45,52]$} \\
\hline$\alpha 5 \beta 1$ & Fn and $\mathrm{LN}$ & $\begin{array}{l}\text { Low levels in normal } \\
\text { human SMCs, and high } \\
\text { expression in cultured } \\
\text { SMCs and during } \\
\text { neointimal hyperplasia }\end{array}$ & $\begin{array}{l}\text { Promote SMC } \\
\text { proliferation and } \\
\text { migration }\end{array}$ & $\begin{array}{l}\text { Mediates early } \\
\text { atherosclerosis }\end{array}$ & $\begin{array}{l}\text { Volocixi-mab } \\
\text { ATN61 }\end{array}$ & {$[41,57,58]$} \\
\hline$\alpha 7 \beta 1$ & LN & $\begin{array}{l}\text { High levels in normal } \\
\text { SMCs, and low } \\
\text { expression in synthetic } \\
\text { SMC }\end{array}$ & $\begin{array}{c}\text { Promotes } \\
\text { contractile SMC } \\
\text { phenotype }\end{array}$ & $\begin{array}{l}\alpha 7 \text { deletion } \\
\text { promotes } \\
\text { neointimal } \\
\text { hyperplasia }\end{array}$ & $\begin{array}{l}\text { No conclusive } \\
\text { reports }\end{array}$ & {$[20,51,59,60]$} \\
\hline$\alpha 8 \beta 1$ & Fn, TN, VN & $\begin{array}{l}\text { Overexpressed in SMCs } \\
\text { that display a } \\
\text { contractile phenotype } \\
\text { low expression in } \\
\text { synthetic SMC } \\
\text { phenotype and during } \\
\text { neointimal hyperplasia }\end{array}$ & $\begin{array}{l}\text { Promotes } \\
\text { contractile SMC } \\
\text { phenotype. } \\
\text { Prevents SMC } \\
\text { proliferation and } \\
\text { migration }\end{array}$ & $\begin{array}{l}\alpha 8 \text { deletion } \\
\text { aggravates } \\
\text { intimal } \\
\text { thickening }\end{array}$ & $\begin{array}{l}\text { No conclusive } \\
\text { reports }\end{array}$ & {$[12,35,50,61]$} \\
\hline$\alpha 9 \beta 1$ & $\begin{array}{l}\text { Fn-EDA, TN, } \\
\text { VCAM }\end{array}$ & $\begin{array}{c}\text { Expression increases in } \\
\text { synthetic SMC } \\
\text { phenotype }\end{array}$ & $\begin{array}{l}\text { Promotes SMC } \\
\text { proliferation, } \\
\text { migration, and } \\
\text { synthetic } \\
\text { phenotype. }\end{array}$ & $\begin{array}{l}\alpha 9 \text { deletion } \\
\text { prevents NH }\end{array}$ & ASP5094 & {$[21,62]$} \\
\hline$\alpha v \beta 1$ & VN, Fn & $\begin{array}{l}\text { Weakly expressed in } \\
\text { normal SMCs, and } \\
\text { upregulated in SMCs } \\
\text { cultured on fibronectin }\end{array}$ & $\begin{array}{l}\text { Inhibits } \\
\text { contractility in } \\
\text { SMC exposed to } \\
\text { serum }\end{array}$ & $\begin{array}{l}\text { No conclusive } \\
\text { reports }\end{array}$ & $\begin{array}{l}\text { PLN-74809 } \\
\text { PLN-1474 }\end{array}$ & {$[41,63,64]$} \\
\hline$\alpha v \beta 3$ & VN, OPN, Fn & $\begin{array}{c}\text { Weakly expressed in } \\
\text { normal SMCs, and } \\
\text { upregulated in SMCs } \\
\text { cultured on fibronectin } \\
\text { and during neointimal } \\
\text { hyperplasia }\end{array}$ & $\begin{array}{l}\text { Promotes SMC } \\
\text { adhesion, } \\
\text { proliferation and } \\
\text { migration }\end{array}$ & $\begin{array}{c}\text { Promotes } \\
\text { neointimal } \\
\text { hyperplasia }\end{array}$ & $\begin{array}{c}\text { LM609, Abcixi-mab } \\
\text { (c7E3Fab; ReoPro), } \\
\text { Vitaxin, } \\
\text { Intetumu-mab, } \\
\text { Cillengitide }\end{array}$ & {$[16,41,65-68]$} \\
\hline$\alpha v \beta 5$ & $\begin{array}{l}\text { Fib, Fn, } \\
\text { OPN } \\
\text { VN }\end{array}$ & $\begin{array}{l}\text { highly abundant in } \\
\text { cultured SMCs, } \\
\text { upregulated upon } \\
\text { vascular injury }\end{array}$ & $\begin{array}{l}\text { Promotes SMC } \\
\text { adhesion and } \\
\text { migration }\end{array}$ & $\begin{array}{c}\text { Promotes } \\
\text { neointimal } \\
\text { hyperplasia }\end{array}$ & $\begin{array}{c}\text { LM609 } \\
\text { Intetumu-mab }\end{array}$ & {$[67,69]$} \\
\hline
\end{tabular}

\section{Integrin $\alpha 9$ - An Overlooked Integrin}

Several ECM proteins, which are generally expressed at low levels in normal adult tissues, are highly expressed during vascular remodeling [36,70]. Examples of such proteins include OPN, Tenascin-C, and cellular fibronectin containing EDA (Fn-EDA), all of which are known to promote SMC proliferation and neointimal hyperplasia [71-73]. It is important to note that Fn-EDA contains a non-RGD sequence known to interact with integrin $\alpha 9$ [74]. Furthermore, $\alpha 9$ and its matrix protein ligands associate with and synergize signaling from several growth factors, including PDGF-BB, to promote cell adhesion and 
motility [31,75,76]. In addition, $\alpha 9$ is known to be expressed by SMC [77], suggesting an essential role of $\alpha 9$ in SMC biology. In humans, $\alpha 9$ is encoded by the ITGA9 gene, located in the 3p21.3-22.2 segment of a chromosome, which encodes the polypeptides of 1035 amino acids and has a size of $114.5 \mathrm{KD}$ [78]. The structure of $\alpha 9$ consists of a ligand-binding large $\mathrm{N}$-terminal extracellular domain, a transmembrane segment, and a short C-terminal cytoplasmic domain that specifically binds to intracellular proteins [78]. $\alpha 9$ exclusively heterodimerize with $\beta 1$ subunit, generating $\alpha 9 \beta 1$ heterodimer. Unlike other integrins that recognize RGD sequence, $\alpha 9 \beta 1$ recognizes a Met-Leu-Asp sequence, and it forms a unique subfamily with $\alpha 4 \beta 1$. Initially, due to many shared ligands, $\alpha 9$ was thought to have similar functions to those of $\alpha 4$; however, genetic ablation studies in mice revealed that phenotypes do not overlap, suggesting different functions in vivo [79]. Besides SMCs, integrin $\alpha 9$ is widely distributed throughout airway epithelium, skeletal muscle, endothelial cells, smooth muscle, hepatocytes, neutrophils, and cancer cells and has been shown to have an important role in regulating cell adhesion, migration, wound healing, thrombosis, angiogenesis, and inflammatory and immune responses [80-83].

\section{Role of $\alpha 9 \beta 1$ in SMC Proliferation and Neointimal Hyperplasia}

In recent years, $\alpha 9 \beta 1$ has gained particular attention because of its involvement in many diseases, including rheumatoid arthritis and multiple sclerosis [84]. In quiescent murine and human aortic SMCs, $\alpha 9$ is expressed at low levels and is mainly restricted to a membrane lining. After stimulation with PDGF-BB, which is known to modulate the membrane mobility and trafficking of integrins [85], a higher expression of $\alpha 9$ was detected in the cytoplasm (Figure 2) [21]. SMC-specific deletion of $\alpha 9$ significantly reduces SMC proliferation, migration, phenotypic switching, and injury-mediated pathological remodeling [21]. Previously, it was demonstrated that integrin and growth factor receptors activate the GSK3 $\beta$ signaling pathway [86]. GSK3 $\beta$ is known to phosphorylate $\beta$-catenin, the central signaling molecule of the canonical Wnt pathway, making it available for proteasomal degradation [87]. Nuclear-localized $\beta$-catenin interacts with TCF/LEF family of transcription factors and promotes its target gene expression. $\alpha 9$ deficiency was associated with higher GSK3 $\beta$ activity [86]. Studies suggest that integrin $\alpha 9 \beta 1$ utilizes the common integrin signaling proteins, including FAK, Src, and ERK [30,31]. Utilizing human coronary and mouse aortic SMCs, SMC-specific $\alpha 9$-deficient mice, and blocking antibody to the $\alpha 9$ subunit, we demonstrated that $\alpha 9$ activates FAK, Src, ERK, and p38 pathway and regulates nuclear translocation of $\beta$-catenin. Although the precise molecular mechanism of $\alpha 9 \beta 1$ induced FAK-Src activation remains to be elucidated, we speculate that Src may directly interact with the cytoplasmic tail of $\alpha 9$. Recently, Kurotaki et al. developed anti-integrin $\alpha 9$ antibody (clone 55A2C), which was shown to have an inhibitory effect on the binding of $\alpha 9 / \mathrm{NIH} 3 \mathrm{~T} 3$ cells to the synthetic peptides AEIDGIEL, a sequence similar to the EDGIHEL sequence present in the EDA segment of fibronectin [88]. 55A2C has been shown to have an inhibitory effect on arthritis and multiple sclerosis progression in murine models [84]. We demonstrated that pretreatment with 55A2C suppressed PDGF-induced SMC proliferation and migration and inhibited injury-induced neointimal hyperplasia [21]. 


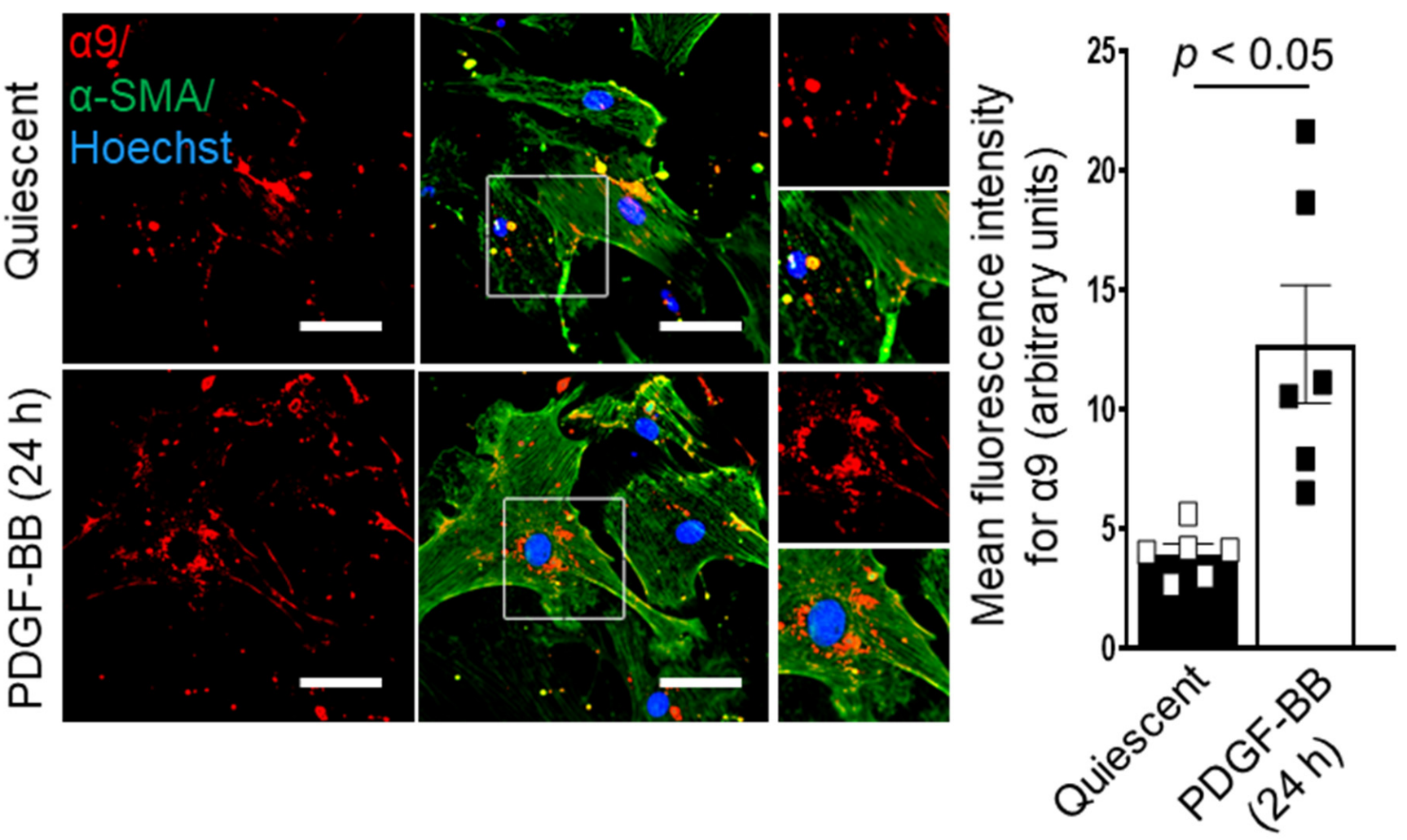

Figure 2. Integrin $\alpha 9$ expression in murine aortic smooth muscle cell (SMC). Serum-starved murine aortic SMC was stimulated with or without platelet-derived growth factor-BB (PDGF-BB) for $24 \mathrm{~h}$. The left panels show representative double immunostaining for $\alpha 9$ (red) and $\alpha \mathrm{SMA}$ (green) in SMCs stimulated with or without PDGF-BB. Boxed regions are magnified. Scale bars: $30 \mu \mathrm{m}$. The right panel shows the quantification of $\alpha 9$ fluorescence intensity ( $n=6$ /group). Statistical analysis: unpaired Student's $t$-test.

\section{Role of Cellular Fibronectin Containing EDA Domain in $\alpha 9$ Mediated SMC Activation}

The predominant isoforms of fibronectin found in the ECM, known as cellular fibronectin ( $\mathrm{cFn}$ ), are dimeric or cross-linked multimeric structures containing either alternatively spliced extra domain A (EDA) or extra domain B (EDB) or both, in varying proportions $[89,90]$. cFn containing EDA (Fn-EDA) in the ECM is synthesized by vascular cells, including endothelial cells, and its expression levels are upregulated during the development of neointima [71,91]. Recently, we demonstrated that PDGF-BB upregulates cellular Fn-EDA in stimulated SMCs, promotes phenotype switching and proliferation via TLR4, and promotes neointimal hyperplasia [71]. Furthermore, using RGDS peptide, we found that Fn-EDA mediates SMC proliferation and migration partially through integrins that are not recognized by RGDS peptide [71]. Notably, $\alpha 9 \beta 1$ regulates the functional activity of SMC through a variety of several non-RGD sequences such as SVVYGLR in OPN [92], AEIDGIEL in Tenascin-C [93], and PEDGIHELFP in cellular Fn containing EDA [88]. In line with these observations, studies using $\alpha 9$-deficient SMCs and recombinant EDA-containing or EDA-lacking peptides found that integrin $\alpha 9$ mediates SMC proliferation, migration, and phenotypic switching partially via Fn-EDA. These studies unequivocally support a causal connection between integrin $\alpha 9$ and FN-EDA in SMC proliferation and neointimal hyperplasia exacerbation.

\section{Anti-Integrin Therapies in SMC Proliferation and Injury-Induced Neointimal Hyperplasia}

Many studies have focused on targeting integrins as an intervention for aberrant SMC proliferation (Table 1). Studies with $\alpha 5 \beta 1$ - and $\alpha \mathrm{v} \beta 3$-specific antagonists, RGD peptide, or 
integrin blocking antibody in a variety of preclinical models demonstrated that targeting of these integrins inhibit proliferation and migration of SMC and prevented neointimal hyperplasia [33,94,95]. Early clinical trials found that Abciximab/c7E3 (a mouse/human chimeric Fab portion of the IgG), integrilin/eptifibatide (an RGD based inhibitor), and AGGRASTAT/Tirofiban (a non-peptide tyrosine derivative) improved early adverse cardiac events after percutaneous coronary interventions (PCI) [47,96-99]. However, subsequent clinical trials did not meet expectations and demonstrated that these antagonists did not prevent intimal hyperplasia $[47,100,101]$. It is important to note that in these clinical trials, integrin antagonists were infused for the short term that primarily inhibited platelet activation. There is a possibility that such a short-term infusion could not block $\alpha v \beta 3$ during vascular restenosis. Therefore, clinical trials specifically designed to assess the long-term effect of integrin-blocking on clinical restenosis are required. Another study tested the safety and efficacy of abciximab-coated stents in native human coronary artery lesions [102]. The 6-month intravascular ultrasound analysis showed that the area of neointimal hyperplasia was significantly smaller in the abciximab-coated stent group than in the control stent group, which indicated abciximab-coated stents to be safe and effective in the prevention of coronary restenosis [103]. Unfortunately, in a 2-year follow-up, abciximab-coated stents did not show superior clinical outcomes over bare-metal stents. Further studies are warranted to confirm these results in large-scale, prospective randomized trials.

Although the results of initial clinical trials with some integrins were disappointing, a study found that stents coated with peptide targeting $\alpha v \beta 3$ decreased neointimal growth and improved vessel healing and reendothelialization in iliac arteries of New Zealand white rabbits [46]. Other preclinical studies demonstrated that targeting integrins with RGD peptides results in reduced neointimal growth $[40,104]$. Still, the clinical development of RGD-based integrin inhibitors has faced significant challenges, as many of these linear peptides have bioavailability and selectivity issues. In addition, many non-RGD recognizing integrin heterodimers contribute to SMC biology. Examples of such integrins include $\alpha 4 \beta 1, \alpha 4 \beta 7$, and $\alpha 9 \beta 1$. Blocking VCAM- 1 and $\alpha 4 \beta 1$ interaction using anti- $\alpha 4$ integrin antibody or $\alpha 4$ integrin inhibitor (ELN 457946) was shown to attenuate neointimal formation [105] and in-stent restenosis [45].

\section{Clinical Perspective}

Balloon angioplasty followed by stent implantation remains the treatment of choice for treating obstructive coronary arteries. However, the procedure is hampered by in-stent restenosis (ISR), a phenomenon mainly characterized by local inflammation leading to aggressive SMC proliferation and late neoatherosclerosis [106]. Though recent drug-eluting stents (DES) have reduced ISR incidence, DES is not immune to restenosis. Routine angiographic data after using newer-generation devices demonstrates rates of angiographic restenosis of approximately 5-10\% [107]. Current guidelines recommend that patients who develop clinical restenosis after DES implantation be considered for repeated PCI with balloon angioplasty or DESs containing the same drug or an alternative antiproliferative drug [108]. Therefore, new therapeutic interventions are required to target vascular pathologies such as atherosclerosis and restenosis and improve clinical outcomes following PCI. Combining targeted integrin therapy with PCI procedures may prevent the recurrence of stent-induced restenosis. Currently, several approaches are available to target integrins, including monoclonal antibodies, peptide inhibitors, and RGD-mimetic small-molecule inhibitors. However, none of them are commercialized for cardiovascular indications because of limitations. First, preclinical small animal models of neointimal hyperplasia do not mimic clinical settings and could be one of the major contributing factors to the lack of reproducibility of preclinical findings. Second, regulation of integrins is a very complex, dynamic, and quick process [109]. The levels of different integrin heterodimer such as $\alpha \mathrm{v} \beta 3, \alpha \mathrm{v} \beta 5$, or $\alpha 5 \beta 1$, expressed by SMCs may differ during the process of neointima formation, leading to a dynamic change in integrin pattern. By understanding the regional 
and temporal regulation of integrin expression's during SMC migration and phenotypic modulation, we may see more success in developing new interventions.

\section{Conclusions and Future Perspectives}

Integrins are cell surface receptors that are involved in mediating cell-cell interaction and cell-ECM interactions. SMCs express several integrins, which are differentially expressed depending on the phenotypic state. Multiple mechanisms regulate integrin bi-directional signaling in SMC, enabling them to proliferate, migrate, and differentiate into synthetic phenotype. Previous preclinical and clinical studies emphasizing $\alpha \mathrm{v} \beta 3$ and $\alpha \mathrm{v} \beta 5$ for inhibition of restenosis were met with failures. Nevertheless, understanding the role of other integrins in SMC biology could lead to new interventions to combat restenosis.

Author Contributions: M.J.; writing original draft, A.K.C.; review and editing. All authors have read and agreed to the published version of the manuscript.

Funding: M.J. lab is supported by Ramalingaswami Re-entry Fellowship grant from the Department of Biotechnology, Government of India (BT/RLF/Re-entry/28/2019). AKC lab is supported by grants from the National Institutes of Health grant (R35HL139926, R01NS109910 \& U01NS113388) and by the Established Investigator Award 18EIA33900009 from American Heart Association.

Institutional Review Board Statement: Not applicable.

Informed Consent Statement: Not applicable.

Data Availability Statement: Not applicable.

Conflicts of Interest: The authors declare no conflict of interest.

\section{References}

1. Allahverdian, S.; Chaabane, C.; Boukais, K.; Francis, G.A.; Bochaton-Piallat, M.L. Smooth muscle cell fate and plasticity in atherosclerosis. Cardiovasc. Res. 2018, 114, 540-550. [CrossRef] [PubMed]

2. Sorokin, V.; Vickneson, K.; Kofidis, T.; Woo, C.C.; Lin, X.Y.; Foo, R.; Shanahan, C.M. Role of Vascular Smooth Muscle Cell Plasticity and Interactions in Vessel Wall Inflammation. Front. Immunol. 2020, 11, 599415. [CrossRef] [PubMed]

3. Chakraborty, R.; Chatterjee, P.; Dave, J.M.; Ostriker, A.C.; Greif, D.M.; Rzucidlo, E.M.; Martin, K.A. Targeting smooth muscle cell phenotypic switching in vascular disease. JVS Vasc. Sci. 2021, 2, 79-94. [CrossRef] [PubMed]

4. Jain, M.; Dhanesha, N.; Doddapattar, P.; Nayak, M.K.; Guo, L.; Cornelissen, A.; Lentz, S.R.; Finn, A.V.; Chauhan, A.K. Smooth Muscle Cell-Specific PKM2 (Pyruvate Kinase Muscle 2) Promotes Smooth Muscle Cell Phenotypic Switching and Neointimal Hyperplasia. Arterioscler. Thromb. Vasc. Biol. 2021, 41, 1724-1737. [CrossRef]

5. Jain, M.; Singh, A.; Singh, V.; Maurya, P.; Barthwal, M.K. Gingerol Inhibits Serum-Induced Vascular Smooth Muscle Cell Proliferation and Injury-Induced Neointimal Hyperplasia by Suppressing p38 MAPK Activation. J. Cardiovasc. Pharmacol. Ther. 2016, 21, 187-200. [CrossRef]

6. Jain, M.; Singh, A.; Singh, V.; Barthwal, M.K. Involvement of interleukin-1 receptor-associated kinase-1 in vascular smooth muscle cell proliferation and neointimal formation after rat carotid injury. Arterioscler. Thromb. Vasc. Biol. 2015, 35, 1445-1455. [CrossRef]

7. Shankman, L.S.; Gomez, D.; Cherepanova, O.A.; Salmon, M.; Alencar, G.F.; Haskins, R.M.; Swiatlowska, P.; Newman, A.A.; Greene, E.S.; Straub, A.C.; et al. KLF4-dependent phenotypic modulation of smooth muscle cells has a key role in atherosclerotic plaque pathogenesis. Nat. Med. 2015, 21, 628-637. [CrossRef]

8. Thyberg, J.; Blomgren, K.; Roy, J.; Tran, P.K.; Hedin, U. Phenotypic modulation of smooth muscle cells after arterial injury is associated with changes in the distribution of laminin and fibronectin. J. Histochem. Cytochem. 1997, 45, 837-846. [CrossRef]

9. Hedin, U.; Bottger, B.A.; Forsberg, E.; Johansson, S.; Thyberg, J. Diverse effects of fibronectin and laminin on phenotypic properties of cultured arterial smooth muscle cells. J. Cell Biol. 1988, 107, 307-319. [CrossRef]

10. Moiseeva, E.P. Adhesion receptors of vascular smooth muscle cells and their functions. Cardiovasc. Res. 2001, 52, 372-386. [CrossRef]

11. Lim, I.R.; Kim, C.; Jung, J.W.; Kim, J.H.; Hong, S.J. Inhibition of Smooth Muscle Cell Proliferation and Migration by a Talin Modulator Attenuates Neointimal Formation after Femoral Arterial Injury. Korean Circ. J. 2020, 50, 613-624. [CrossRef] [PubMed]

12. Zargham, R.; Thibault, G. Alpha 8 integrin expression is required for maintenance of the smooth muscle cell differentiated phenotype. Cardiovasc. Res. 2006, 71, 170-178. [CrossRef] [PubMed]

13. Bandaru, S.; Ala, C.; Zhou, A.X.; Akyurek, L.M. Filamin A Regulates Cardiovascular Remodeling. Int. J. Mol. Sci. 2021, $22,6555$. [CrossRef] [PubMed]

14. Mezu-Ndubuisi, O.J.; Maheshwari, A. The role of integrins in inflammation and angiogenesis. Pediatr. Res. 2021, 89, 1619-1626. [CrossRef] [PubMed] 
15. Morse, E.M.; Brahme, N.N.; Calderwood, D.A. Integrin cytoplasmic tail interactions. Biochemistry 2014, 53, 810-820. [CrossRef] [PubMed]

16. Mawatari, K.; Liu, B.; Kent, K.C. Activation of integrin receptors is required for growth factor-induced smooth muscle cell dysfunction. J. Vasc. Surg. 2000, 31, 375-381. [CrossRef]

17. Yamada, K.M.; Even-Ram, S. Integrin regulation of growth factor receptors. Nat. Cell Biol. 2002, 4, E75-E76. [CrossRef]

18. Pickering, J.G.; Chow, L.H.; Li, S.; Rogers, K.A.; Rocnik, E.F.; Zhong, R.; Chan, B.M. alpha5beta1 integrin expression and luminal edge fibronectin matrix assembly by smooth muscle cells after arterial injury. Am. J. Pathol. 2000, 156, 453-465. [CrossRef]

19. Martinez-Lemus, L.A.; Wu, X.; Wilson, E.; Hill, M.A.; Davis, G.E.; Davis, M.J.; Meininger, G.A. Integrins as unique receptors for vascular control. J. Vasc. Res. 2003, 40, 211-233. [CrossRef]

20. Raines, E.W.; Bornfeldt, K.E. Integrin alpha(7)beta(1) COMPels smooth muscle cells to maintain their quiescence. Circ. Res. 2010, 106, 427-429. [CrossRef]

21. Jain, M.; Dev, R.; Doddapattar, P.; Kon, S.; Dhanesha, N.; Chauhan, A.K. Integrin alpha9 regulates smooth muscle cell phenotype switching and vascular remodeling. JCI Insight 2021, 6, e147134. [CrossRef] [PubMed]

22. Berditchevski, F.; Odintsova, E. Characterization of integrin-tetraspanin adhesion complexes: Role of tetraspanins in integrin signaling. J. Cell Biol. 1999, 146, 477-492. [CrossRef] [PubMed]

23. Chang, A.W.; Kuo, A.; Barnathan, E.S.; Okada, S.S. Urokinase receptor-dependent upregulation of smooth muscle cell adhesion to vitronectin by urokinase. Arterioscler. Thromb. Vasc. Biol. 1998, 18, 1855-1860. [CrossRef] [PubMed]

24. Ho, B.; Bendeck, M.P. Integrin linked kinase (ILK) expression and function in vascular smooth muscle cells. Cell Adh. Migr. 2009, 3, 174-176. [CrossRef]

25. Ribeiro-Silva, J.C.; Miyakawa, A.A.; Krieger, J.E. Focal adhesion signaling: Vascular smooth muscle cell contractility beyond calcium mechanisms. Clin. Sci. 2021, 135, 1189-1207. [CrossRef] [PubMed]

26. Eliceiri, B.P. Integrin and growth factor receptor crosstalk. Circ. Res. 2001, 89, 1104-1110. [CrossRef] [PubMed]

27. Schwartz, M.A.; Baron, V. Interactions between mitogenic stimuli, or, a thousand and one connections. Curr. Opin. Cell Biol. 1999, 11, 197-202. [CrossRef]

28. Li, M.; Wang, Y.; Li, M.; Wu, X.; Setrerrahmane, S.; Xu, H. Integrins as attractive targets for cancer therapeutics. Acta Pharm. Sin. B 2021, 11, 2726-2737. [CrossRef] [PubMed]

29. Moro, L.; Dolce, L.; Cabodi, S.; Bergatto, E.; Boeri Erba, E.; Smeriglio, M.; Turco, E.; Retta, S.F.; Giuffrida, M.G.; Venturino, M.; et al Integrin-induced epidermal growth factor (EGF) receptor activation requires c-Src and p130Cas and leads to phosphorylation of specific EGF receptor tyrosines. J. Biol. Chem. 2002, 277, 9405-9414. [CrossRef]

30. Gupta, S.K.; Vlahakis, N.E. Integrin alpha9beta1 mediates enhanced cell migration through nitric oxide synthase activity regulated by Src tyrosine kinase. J. Cell Sci. 2009, 122, 2043-2054. [CrossRef]

31. Gupta, S.K.; Vlahakis, N.E. Integrin alpha9beta1: Unique signaling pathways reveal diverse biological roles. Cell Adh. Migr. 2010, 4, 194-198. [CrossRef] [PubMed]

32. Srivatsa, S.S.; Fitzpatrick, L.A.; Tsao, P.W.; Reilly, T.M.; Holmes, D.R., Jr.; Schwartz, R.S.; Mousa, S.A. Selective alpha v beta 3 integrin blockade potently limits neointimal hyperplasia and lumen stenosis following deep coronary arterial stent injury: Evidence for the functional importance of integrin alpha $v$ beta 3 and osteopontin expression during neointima formation. Cardiovasc. Res. 1997, 36, 408-428. [CrossRef] [PubMed]

33. Bunni, M.A.; Kramarenko, I.I.; Walker, L.; Raymond, J.R.; Garnovskaya, M.N. Role of integrins in angiotensin II-induced proliferation of vascular smooth muscle cells. Am. J. Physiol. Cell Physiol. 2011, 300, C647-C656. [CrossRef] [PubMed]

34. Bolas, G.; de Rezende, F.F.; Lorente, C.; Sanz, L.; Eble, J.A.; Calvete, J.J. Inhibitory effects of recombinant RTS-jerdostatin on integrin alpha1beta1 function during adhesion, migration and proliferation of rat aortic smooth muscle cells and angiogenesis. Toxicon 2014, 79, 45-54. [CrossRef]

35. Zargham, R.; Thibault, G. alpha8beta1 Integrin expression in the rat carotid artery: Involvement in smooth muscle cell migration and neointima formation. Cardiovasc. Res. 2005, 65, 813-822. [CrossRef]

36. Xu, J.; Shi, G.P. Vascular wall extracellular matrix proteins and vascular diseases. Biochim. Biophys. Acta 2014, 1842, 2106-2119. [CrossRef]

37. Dufourcq, P.; Couffinhal, T.; Alzieu, P.; Daret, D.; Moreau, C.; Duplaa, C.; Bonnet, J. Vitronectin is up-regulated after vascular injury and vitronectin blockade prevents neointima formation. Cardiovasc. Res. 2002, 53, 952-962. [CrossRef]

38. Duplaa, C.; Couffinhal, T.; Dufourcq, P.; Llanas, B.; Moreau, C.; Bonnet, J. The integrin very late antigen-4 is expressed in human smooth muscle cell. Involvement of alpha 4 and vascular cell adhesion molecule-1 during smooth muscle cell differentiation. Circ. Res. 1997, 80, 159-169. [CrossRef]

39. Grenache, D.G.; Coleman, T.; Semenkovich, C.F.; Santoro, S.A.; Zutter, M.M. Alpha2beta1 integrin and development of atherosclerosis in a mouse model: Assessment of risk. Arterioscler. Thromb. Vasc. Biol. 2003, 23, 2104-2109. [CrossRef]

40. Choi, E.T.; Engel, L.; Callow, A.D.; Sun, S.; Trachtenberg, J.; Santoro, S.; Ryan, U.S. Inhibition of neointimal hyperplasia by blocking alpha V beta 3 integrin with a small peptide antagonist GpenGRGDSPCA. J. Vasc. Surg. 1994, 19, 125-134. [CrossRef]

41. Cai, W.J.; Li, M.B.; Wu, X.; Wu, S.; Zhu, W.; Chen, D.; Luo, M.; Eitenmuller, I.; Kampmann, A.; Schaper, J.; et al. Activation of the integrins alpha 5beta 1 and alpha v beta 3 and focal adhesion kinase (FAK) during arteriogenesis. Mol. Cell. Biochem. 2009, 322, 161-169. [CrossRef] 
42. Skinner, M.P.; Raines, E.W.; Ross, R. Dynamic expression of alpha 1 beta 1 and alpha 2 beta 1 integrin receptors by human vascular smooth muscle cells. Alpha 2 beta 1 integrin is required for chemotaxis across type I collagen-coated membranes. Am. J. Pathol. 1994, 145, 1070-1081.

43. Azrin, M.A.; Ling, F.S.; Chen, Q.; Pawashe, A.; Migliaccio, F.; Homer, R.; Todd, M.; Ezekowitz, M.D. Preparation, characterization, and evaluation of a monoclonal antibody against the rabbit platelet glycoprotein IIb/IIIa in an experimental angioplasty model. Circ. Res. 1994, 75, 268-277. [CrossRef]

44. Lumsden, A.B.; Chen, C.; Hughes, J.D.; Kelly, A.B.; Hanson, S.R.; Harker, L.A. Anti-VLA-4 antibody reduces intimal hyperplasia in the endarterectomized carotid artery in nonhuman primates. J. Vasc. Surg. 1997, 26, 87-93. [CrossRef]

45. Braun, A.; Dofiles, L.; Rousselle, S.; Guerrero, L.; Gunther, J.; Yednock, T.; Stricker-Krongrad, A.; Messersmith, E. Effects of an alpha-4 integrin inhibitor on restenosis in a new porcine model combining endothelial denudation and stent placement. PLoS ONE 2010, 5, e14314. [CrossRef] [PubMed]

46. Rechenmacher, F.; Steigerwald, K.; Laufer, B.; Neubauer, S.; Kapp, T.G.; Li, L.; Mas-Moruno, C.; Joner, M.; Kessler, H. The integrin ligand $c(\operatorname{RGDf}(\mathrm{NMe}) \mathrm{Nal})$ reduces neointimal hyperplasia in a polymer-free drug-eluting stent system. ChemMedChem 2014, 9, 1413-1418. [CrossRef]

47. Kokubo, T.; Uchida, H.; Choi, E.T. Integrin alpha(v)beta(3) as a target in the prevention of neointimal hyperplasia. J. Vasc. Surg. 2007, 45 (Suppl. A), A33-A38. [CrossRef] [PubMed]

48. Panchatcharam, M.; Miriyala, S.; Yang, F.; Leitges, M.; Chrzanowska-Wodnicka, M.; Quilliam, L.A.; Anaya, P.; Morris, A.J.; Smyth, S.S. Enhanced proliferation and migration of vascular smooth muscle cells in response to vascular injury under hyperglycemic conditions is controlled by beta3 integrin signaling. Int. J. Biochem. Cell Biol. 2010, 42, 965-974. [CrossRef]

49. Smyth, S.S.; Reis, E.D.; Zhang, W.; Fallon, J.T.; Gordon, R.E.; Coller, B.S. Beta(3)-integrin-deficient mice but not P-selectin-deficient mice develop intimal hyperplasia after vascular injury: Correlation with leukocyte recruitment to adherent platelets 1 hour after injury. Circulation 2001, 103, 2501-2507. [CrossRef] [PubMed]

50. Menendez-Castro, C.; Cordasic, N.; Neureiter, D.; Amann, K.; Marek, I.; Volkert, G.; Stintzing, S.; Jahn, A.; Rascher, W.; Hilgers, K.F.; et al. Under-expression of alpha8 integrin aggravates experimental atherosclerosis. J. Pathol. 2015, 236, 5-16. [CrossRef]

51. Welser, J.V.; Lange, N.; Singer, C.A.; Elorza, M.; Scowen, P.; Keef, K.D.; Gerthoffer, W.T.; Burkin, D.J. Loss of the alpha7 integrin promotes extracellular signal-regulated kinase activation and altered vascular remodeling. Circ. Res. 2007, 101, 672-681. [CrossRef] [PubMed]

52. Raab-Westphal, S.; Marshall, J.F.; Goodman, S.L. Integrins as Therapeutic Targets: Successes and Cancers. Cancers 2017, 9, 110. [CrossRef] [PubMed]

53. Schapira, K.; Lutgens, E.; de Fougerolles, A.; Sprague, A.; Roemen, A.; Gardner, H.; Koteliansky, V.; Daemen, M.; Heeneman, S. Genetic deletion or antibody blockade of alpha1beta1 integrin induces a stable plaque phenotype in ApoE-/- mice. Arterioscler Thromb. Vasc. Biol. 2005, 25, 1917-1924. [CrossRef]

54. Lee, R.T.; Berditchevski, F.; Cheng, G.C.; Hemler, M.E. Integrin-mediated collagen matrix reorganization by cultured human vascular smooth muscle cells. Circ. Res. 1995, 76, 209-214. [CrossRef]

55. Obata, H.; Hayashi, K.; Nishida, W.; Momiyama, T.; Uchida, A.; Ochi, T.; Sobue, K. Smooth muscle cell phenotype-dependent transcriptional regulation of the alpha1 integrin gene. J. Biol. Chem. 1997, 272, 26643-26651. [CrossRef]

56. Pickering, J.G.; Uniyal, S.; Ford, C.M.; Chau, T.; Laurin, M.A.; Chow, L.H.; Ellis, C.G.; Fish, J.; Chan, B.M. Fibroblast growth factor-2 potentiates vascular smooth muscle cell migration to platelet-derived growth factor: Upregulation of alpha2beta1 integrin and disassembly of actin filaments. Circ. Res. 1997, 80, 627-637. [CrossRef] [PubMed]

57. Song, Y.; Qin, X.; Wang, H.; Miao, R.; Zhang, Y.; Miao, C.; Wang, Z. Effects of integrin alpha5beta1 on the proliferation and migration of human aortic vascular smooth muscle cells. Mol. Med. Rep. 2016, 13, 1147-1155. [CrossRef] [PubMed]

58. Yurdagul, A., Jr.; Green, J.; Albert, P.; McInnis, M.C.; Mazar, A.P.; Orr, A.W. alpha5beta1 integrin signaling mediates oxidized low-density lipoprotein-induced inflammation and early atherosclerosis. Arterioscler. Thromb. Vasc. Biol. 2014, 34, 1362-1373. [CrossRef] [PubMed]

59. Wang, L.; Zheng, J.; Du, Y.; Huang, Y.; Li, J.; Liu, B.; Liu, C.J.; Zhu, Y.; Gao, Y.; Xu, Q.; et al. Cartilage oligomeric matrix protein maintains the contractile phenotype of vascular smooth muscle cells by interacting with alpha(7)beta(1) integrin. Circ. Res. 2010, 106, 514-525. [CrossRef] [PubMed]

60. Yao, C.C.; Breuss, J.; Pytela, R.; Kramer, R.H. Functional expression of the alpha 7 integrin receptor in differentiated smooth muscle cells. J. Cell Sci. 1997, 110 Pt 13, 1477-1487. [CrossRef]

61. Zargham, R.; Touyz, R.M.; Thibault, G. alpha 8 Integrin overexpression in de-differentiated vascular smooth muscle cells attenuates migratory activity and restores the characteristics of the differentiated phenotype. Atherosclerosis 2007, 195, 303-312. [CrossRef] [PubMed]

62. Takeuchi, T.; Tanaka, Y.; Erdman, J.; Kaneko, Y.; Saito, M.; Higashitani, C.; Smulders, R.; Lademacher, C. ASP5094, a humanized monoclonal antibody against integrin alpha-9, did not show efficacy in patients with rheumatoid arthritis refractory to methotrexate: Results from a phase 2a, randomized, double-blind, placebo-controlled trial. Arthritis Res. Ther. 2020, 22, 252. [CrossRef] [PubMed]

63. Cully, M. Integrin-targeted therapies branch out. Nat. Rev. Drug Discov. 2020, 19, 739-741. [CrossRef] [PubMed]

64. Slack, R.J.; Macdonald, S.J.F.; Roper, J.A.; Jenkins, R.G.; Hatley, R.J.D. Emerging therapeutic opportunities for integrin inhibitors. Nat. Rev. Drug Discov. 2021, 21, 60-78. [CrossRef] 
65. Hoshiga, M.; Alpers, C.E.; Smith, L.L.; Giachelli, C.M.; Schwartz, S.M. Alpha-v beta-3 integrin expression in normal and atherosclerotic artery. Circ. Res. 1995, 77, 1129-1135. [CrossRef]

66. Van der Zee, R.; Murohara, T.; Passeri, J.; Kearney, M.; Cheresh, D.A.; Isner, J.M. Reduced intimal thickening following alpha(v)beta3 blockade is associated with smooth muscle cell apoptosis. Cell Adhes. Commun. 1998, 6, 371-379. [CrossRef]

67. Liaw, L.; Skinner, M.P.; Raines, E.W.; Ross, R.; Cheresh, D.A.; Schwartz, S.M.; Giachelli, C.M. The adhesive and migratory effects of osteopontin are mediated via distinct cell surface integrins. Role of alpha v beta 3 in smooth muscle cell migration to osteopontin in vitro. J. Clin. Investig. 1995, 95, 713-724. [CrossRef]

68. Bendeck, M.P.; Irvin, C.; Reidy, M.; Smith, L.; Mulholland, D.; Horton, M.; Giachelli, C.M. Smooth muscle cell matrix metalloproteinase production is stimulated via alpha(v)beta(3) integrin. Arterioscler. Thromb. Vasc. Biol. 2000, 20, 1467-1472. [CrossRef]

69. Lee, B.H.; Bae, J.S.; Park, R.W.; Kim, J.E.; Park, J.Y.; Kim, I.S. betaig-h3 triggers signaling pathways mediating adhesion and migration of vascular smooth muscle cells through alphavbeta5 integrin. Exp. Mol. Med. 2006, 38, 153-161. [CrossRef]

70. Ma, Z.; Mao, C.; Jia, Y.; Fu, Y.; Kong, W. Extracellular matrix dynamics in vascular remodeling. Am. J. Physiol. Cell Physiol. 2020, 319, C481-C499. [CrossRef]

71. Jain, M.; Dhanesha, N.; Doddapattar, P.; Chorawala, M.R.; Nayak, M.K.; Cornelissen, A.; Guo, L.; Finn, A.V.; Lentz, S.R.; Chauhan, A.K. Smooth muscle cell-specific fibronectin-EDA mediates phenotypic switching and neointimal hyperplasia. J. Clin. Investig. 2020, 130, 295-314. [CrossRef]

72. Isoda, K.; Nishikawa, K.; Kamezawa, Y.; Yoshida, M.; Kusuhara, M.; Moroi, M.; Tada, N.; Ohsuzu, F. Osteopontin plays an important role in the development of medial thickening and neointimal formation. Circ. Res. 2002, 91, 77-82. [CrossRef] [PubMed]

73. Yamamoto, K.; Onoda, K.; Sawada, Y.; Fujinaga, K.; Imanaka-Yoshida, K.; Shimpo, H.; Yoshida, T.; Yada, I. Tenascin-C is an essential factor for neointimal hyperplasia after aortotomy in mice. Cardiovasc. Res. 2005, 65, 737-742. [CrossRef] [PubMed]

74. Marcinkiewicz, C.; Taooka, Y.; Yokosaki, Y.; Calvete, J.J.; Marcinkiewicz, M.M.; Lobb, R.R.; Niewiarowski, S.; Sheppard, D. Inhibitory effects of MLDG-containing heterodimeric disintegrins reveal distinct structural requirements for interaction of the integrin alpha 9beta 1 with VCAM-1, tenascin-C., and osteopontin. J. Biol. Chem. 2000, 275, 31930-31937. [CrossRef] [PubMed]

75. Emori, T.; Hirose, J.; Ise, K.; Yomoda, J.I.; Kasahara, M.; Shinkuma, T.; Yoshitomi, H.; Ito, H.; Hashimoto, M.; Sugahara, S.; et al. Constitutive Activation of Integrin alpha9 Augments Self-Directed Hyperplastic and Proinflammatory Properties of Fibroblast-like Synoviocytes of Rheumatoid Arthritis. J. Immunol. 2017, 199, 3427-3436. [CrossRef]

76. Vlahakis, N.E.; Young, B.A.; Atakilit, A.; Sheppard, D. The lymphangiogenic vascular endothelial growth factors VEGF-C and -D are ligands for the integrin alpha9beta1. J. Biol. Chem. 2005, 280, 4544-4552. [CrossRef]

77. Huang, B.; Niu, Y.; Chen, Z.; Yang, Y.; Wang, X. Integrin alpha9 is involved in the pathopoiesis of acute aortic dissection via mediating phenotype switch of vascular smooth muscle cell. Biochem. Biophys. Res. Commun. 2020, 533, 519-525. [CrossRef]

78. Xu, S.; Zhang, T.; Cao, Z.; Zhong, W.; Zhang, C.; Li, H.; Song, J. Integrin-alpha9beta1 as a Novel Therapeutic Target for Refractory Diseases: Recent Progress and Insights. Front. Immunol. 2021, 12, 638400. [CrossRef]

79. Yang, J.T.; Rayburn, H.; Hynes, R.O. Cell adhesion events mediated by alpha 4 integrins are essential in placental and cardiac development. Development 1995, 121, 549-560. [CrossRef]

80. Palmer, E.L.; Ruegg, C.; Ferrando, R.; Pytela, R.; Sheppard, D. Sequence and tissue distribution of the integrin alpha 9 subunit, a novel partner of beta 1 that is widely distributed in epithelia and muscle. J. Cell Biol. 1993, 123, 1289-1297. [CrossRef]

81. Singh, P.; Reimer, C.L.; Peters, J.H.; Stepp, M.A.; Hynes, R.O.; Van De Water, L. The spatial and temporal expression patterns of integrin alpha9beta1 and one of its ligands, the EIIIA segment of fibronectin, in cutaneous wound healing. J. Investig. Dermatol. 2004, 123, 1176-1181. [CrossRef] [PubMed]

82. Dhanesha, N.; Jain, M.; Tripathi, A.K.; Doddapattar, P.; Chorawala, M.; Bathla, G.; Nayak, M.K.; Ghatge, M.; Lentz, S.R.; Kon, S.; et al. Targeting Myeloid-Specific Integrin alpha9beta1 Improves Short- and Long-Term Stroke Outcomes in Murine Models with Preexisting Comorbidities by Limiting Thrombosis and Inflammation. Circ. Res. 2020, 126, 1779-1794. [CrossRef]

83. Dhanesha, N.; Nayak, M.K.; Doddapattar, P.; Jain, M.; Flora, G.D.; Kon, S.; Chauhan, A.K. Targeting myeloid-cell specific integrin alpha9beta1 inhibits arterial thrombosis in mice. Blood 2020, 135, 857-861. [CrossRef]

84. Kon, S.; Uede, T. The role of alpha9beta1 integrin and its ligands in the development of autoimmune diseases. J. Cell Commun. Signal. 2018, 12, 333-342. [CrossRef] [PubMed]

85. Ahlen, K.; Ring, P.; Tomasini-Johansson, B.; Holmqvist, K.; Magnusson, K.E.; Rubin, K. Platelet-derived growth factor-BB modulates membrane mobility of beta1 integrins. Biochem. Biophys. Res. Commun. 2004, 314, 89-96. [CrossRef] [PubMed]

86. Wang, Z.; Li, Y.; Xiao, Y.; Lin, H.P.; Yang, P.; Humphries, B.; Gao, T.; Yang, C. Integrin alpha9 depletion promotes beta-catenin degradation to suppress triple-negative breast cancer tumor growth and metastasis. Int. J. Cancer 2019, 145, 2767-2780. [CrossRef] [PubMed]

87. Behrens, J.; Jerchow, B.A.; Wurtele, M.; Grimm, J.; Asbrand, C.; Wirtz, R.; Kuhl, M.; Wedlich, D.; Birchmeier, W. Functional interaction of an axin homolog, conductin, with beta-catenin, APC, and GSK3beta. Science 1998, 280, 596-599. [CrossRef]

88. Liao, Y.F.; Gotwals, P.J.; Koteliansky, V.E.; Sheppard, D.; Van De Water, L. The EIIIA segment of fibronectin is a ligand for integrins alpha 9 beta 1 and alpha 4 beta 1 providing a novel mechanism for regulating cell adhesion by alternative splicing. J. Biol. Chem. 2002, 277, 14467-14474. [CrossRef] [PubMed] 
89. Doddapattar, P.; Dev, R.; Jain, M.; Dhanesha, N.; Chauhan, A.K. Differential Roles of Endothelial Cell-Derived and Smooth Muscle Cell-Derived Fibronectin Containing Extra Domain A in Early and Late Atherosclerosis. Arterioscler. Thromb. Vasc. Biol. 2020, 40, 1738-1747. [CrossRef]

90. Chorawala, M.R.; Prakash, P.; Doddapattar, P.; Jain, M.; Dhanesha, N.; Chauhan, A.K. Deletion of Extra Domain A of Fibronectin Reduces Acute Myocardial Ischaemia/Reperfusion Injury in Hyperlipidaemic Mice by Limiting Thrombo-Inflammation. Thromb. Haemost. 2018, 118, 1450-1460. [CrossRef]

91. Peters, J.H.; Maunder, R.J.; Woolf, A.D.; Cochrane, C.G.; Ginsberg, M.H. Elevated plasma levels of ED1+ ("cellular") fibronectin in patients with vascular injury. J. Lab. Clin. Med. 1989, 113, 586-597. [PubMed]

92. Yokosaki, Y.; Matsuura, N.; Sasaki, T.; Murakami, I.; Schneider, H.; Higashiyama, S.; Saitoh, Y.; Yamakido, M.; Taooka, Y.; Sheppard, D. The integrin alpha(9)beta(1) binds to a novel recognition sequence (SVVYGLR) in the thrombin-cleaved amino-terminal fragment of osteopontin. J. Biol. Chem. 1999, 274, 36328-36334. [CrossRef] [PubMed]

93. Yokosaki, Y.; Matsuura, N.; Higashiyama, S.; Murakami, I.; Obara, M.; Yamakido, M.; Shigeto, N.; Chen, J.; Sheppard, D. Identification of the ligand binding site for the integrin alpha9 beta1 in the third fibronectin type III repeat of tenascin-C. J. Biol. Chem. 1998, 273, 11423-11428. [CrossRef] [PubMed]

94. Sheu, J.R.; Wu, C.H.; Chen, Y.C.; Hsiao, G.; Lin, C.H. Mechanisms in the inhibition of neointimal hyperplasia with triflavin in a rat model of balloon angioplasty. J. Lab. Clin. Med. 2001, 137, 270-278. [CrossRef]

95. Baron, J.H.; Moiseeva, E.P.; de Bono, D.P.; Abrams, K.R.; Gershlick, A.H. Inhibition of vascular smooth muscle cell adhesion and migration by c7E3 Fab (abciximab): A possible mechanism for influencing restenosis. Cardiovasc. Res. 2000, 48, 464-472. [CrossRef]

96. Randomised placebo-controlled trial of effect of eptifibatide on complications of percutaneous coronary intervention: IMPACT-II. Integrilin to Minimise Platelet Aggregation and Coronary Thrombosis-II. Lancet 1997, 349, 1422-1428. [CrossRef]

97. Effects of platelet glycoprotein IIb/IIIa blockade with tirofiban on adverse cardiac events in patients with unstable angina or acute myocardial infarction undergoing coronary angioplasty. The RESTORE Investigators. Randomized Efficacy Study of Tirofiban for Outcomes and REstenosis. Circulation 1997, 96, 1445-1453. [CrossRef]

98. Lincoff, A.M.; Califf, R.M.; Moliterno, D.J.; Ellis, S.G.; Ducas, J.; Kramer, J.H.; Kleiman, N.S.; Cohen, E.A.; Booth, J.E.; Sapp, S.K.; et al. Complementary clinical benefits of coronary-artery stenting and blockade of platelet glycoprotein IIb/IIIa receptors. Evaluation of Platelet IIb/IIIa Inhibition in Stenting Investigators. N. Engl. J. Med. 1999, 341, 319-327. [CrossRef]

99. Topol, E.J.; Califf, R.M.; Weisman, H.F.; Ellis, S.G.; Tcheng, J.E.; Worley, S.; Ivanhoe, R.; George, B.S.; Fintel, D.; Weston, M.; et al. Randomised trial of coronary intervention with antibody against platelet IIb/IIIa integrin for reduction of clinical restenosis: Results at six months. The EPIC Investigators. Lancet 1994, 343, 881-886. [CrossRef]

100. Malik, I.; Poullis, M. Acute platelet inhibition with abciximab does not reduce in-stent restenosis. Circulation 2000, 102, E110. [CrossRef]

101. Gibson, C.M.; Goel, M.; Cohen, D.J.; Piana, R.N.; Deckelbaum, L.I.; Harris, K.E.; King, S.B., 3rd. Six-month angiographic and clinical follow-up of patients prospectively randomized to receive either tirofiban or placebo during angioplasty in the RESTORE trial. Randomized Efficacy Study of Tirofiban for Outcomes and Restenosis. J. Am. Coll. Cardiol. 1998, 32, 28-34. [CrossRef]

102. Kim, W.; Jeong, M.H.; Hong, Y.J.; Lee, S.H.; Park, W.S.; Kim, J.H.; Kim, I.S.; Choi, M.J.; Ahn, Y.K.; Cho, J.G.; et al. The long-term clinical results of a platelet glycoprotein IIb/IIIa receptor blocker (Abciximab: Reopro) coated stent in patients with coronary artery disease. Korean J. Intern. Med. 2004, 19, 220-229. [CrossRef] [PubMed]

103. Kim, S.S.; Hong, Y.J.; Jeong, M.H.; Kim, W.; Kim, H.K.; Ko, J.S.; Lee, M.G.; Sim, D.S.; Park, K.H.; Yoon, N.S.; et al. Two-year clinical outcome after abciximab-coated stent implantation in patients with coronary artery disease. Circ. J. 2010, 74, 442-448. [CrossRef] [PubMed]

104. Blindt, R.; Vogt, F.; Astafieva, I.; Fach, C.; Hristov, M.; Krott, N.; Seitz, B.; Kapurniotu, A.; Kwok, C.; Dewor, M.; et al. A novel drug-eluting stent coated with an integrin-binding cyclic Arg-Gly-Asp peptide inhibits neointimal hyperplasia by recruiting endothelial progenitor cells. J. Am. Coll. Cardiol. 2006, 47, 1786-1795. [CrossRef]

105. Barringhaus, K.G.; Phillips, J.W.; Thatte, J.S.; Sanders, J.M.; Czarnik, A.C.; Bennett, D.K.; Ley, K.F.; Sarembock, I.J. Alpha4beta1 integrin (VLA-4) blockade attenuates both early and late leukocyte recruitment and neointimal growth following carotid injury in apolipoprotein E (-/-) mice. J. Vasc. Res. 2004, 41, 252-260. [CrossRef] [PubMed]

106. Alfonso, F.; Byrne, R.A.; Rivero, F.; Kastrati, A. Current treatment of in-stent restenosis. J. Am. Coll. Cardiol. 2014, 63, 2659-2673. [CrossRef]

107. Aoki, J.; Tanabe, K. Mechanisms of drug-eluting stent restenosis. Cardiovasc. Interv. Ther. 2020, 36, 23-29. [CrossRef] [PubMed]

108. Shlofmitz, E.; Iantorno, M.; Waksman, R. Restenosis of Drug-Eluting Stents: A New Classification System Based on Disease Mechanism to Guide Treatment and State-of-the-Art Review. Circ. Cardiovasc. Interv. 2019, 12, e007023. [CrossRef]

109. Walsh, N.; Clynes, M.; Crown, J.; O'Donovan, N. Alterations in integrin expression modulates invasion of pancreatic cancer cells. J. Exp. Clin. Cancer Res. 2009, 28, 140. [CrossRef] 